\title{
Use of space by immature spotted seals (Phoca largha) in Peter the Great Bay (Sea of Japan) breeding area
}

\author{
Vladimir A. Nesterenko* \& Igor O. Katin
}

\begin{abstract}
The terrestrial grouping of the spotted seal Phoca largha (Carnivora, Phocidae) in Peter the Great Bay (Sea of Japan) is one of the smallest (approximately 2,500 individuals) breeding concentration of this species, that is characterized by coastal reproduction. In 2009, 170 seals were hot branded on the islands of the Rimsky-Korsakov Archipelago where all the haulout sites, in which the reproductive ashore associations of spotted seal form and function, are concentrated. Movements of marked animals were monitored year-round between 2009 and 2012, and the spatial distribution of immature seals was studied. Within the breeding area, the use of space by immature seals older than one year was based on the mechanism of "social panmixia" and turned out to be fundamentally different from territory use by underyearlings.
\end{abstract}

KEY WORDS: spotted seal, Phoca largha, branding, use of space, Sea of Japan.

Vladimir A. Nesterenko [vanester@mail.ru], Laboratory of Theriology, Institute of Biology and Soil Science, Far East Branch of the Russian Academy of Sciences, Prospect Stoletiya 159, Vladivostok 690022, Russia; Igor O. Katin [katinpelis@gmail.com], The Scientific and Educational Complex "Primorski Aquarium”, Far East Branch of the Russian Academy of Sciences, Pal'chevskogo str. 17, Vladivostok 690041, Russia.

\section{Использование пространства неполовозрелыми особями ларги (Phoca largha) в местах репродуктивной концентрации в заливе Петра Великого (Японское море)}

\begin{abstract}
В.А. Нестеренко, И.О. Катин
Группировка ларги Phoca largha (Carnivora, Phocidae) в заливе Петра Великого Японского моря, отличительной особенностью которой является береговое размножение тюленей - одна из самых малочисленных репродуктивных концентраций этого вида (около 2500 особей). В 2009 г. 170 особей ларги были помечены пожизненными метками на островах архипелага Римского-Корсакова, где сосредоточены все лежбища, на которых функционируют репродуктивные береговые объединения тюленей. На протяжении 2009-2012 гг. за мечеными особями велось круглогодичное слежение и изучались особенности пространственного размещения неполовозрелых тюленей. Установлено, что использование пространства в зоне репродукции неполовозрелыми старше одного года основано на механизме «социальной панмиксии» и носит принципиально иной характер по сравнению с сеголетками.
\end{abstract}

КЛЮЧЕВЫЕ СЛОВА: ларга, Phoca largha, мечение, использование пространства, Японское море.

Spotted seal (Phoca largha Pallas, 1811) is one of the most widespread species of true seals in the North Pacific. Out of eight breeding concentrations (Shaughnessy \& Fay, 1977) of this species one of the smallest (Boveng et al., 2009) is situated in Peter the Great Bay of the Sea of Japan. In contrast to most of the area where reproduction of the spotted seal takes place on ice, the territorial grouping of the species in the south part of the Sea of Japan is characterized by coastal reproduction (Nesterenko \& Katin, 2010). The key factor favoring coastal reproduction of the spotted seal in the bay is the presence of the archipelago, which

* Corresponding author consists of small islands with specific geomorphologic structures and shore areas that are optimal for successful pupping and nursing (Katin \& Nesterenko, 2010a). Spotted seals not only breed on islands, but they are also closely connected with the coastal areas all year round (Trukhin \& Katin, 2001). Thus, it is possible to effectively study the trends in use of space by the seals in this region. This behavior remains poorly studied for true seals, and these studies have only recently been initiated for spotted seals (Katin, 2010). This work aims to reveal the use of space by seals during the period between weaning and sexual maturity, based on the year-round monitoring of marked seals born on the islands in Peter the Great Bay. 


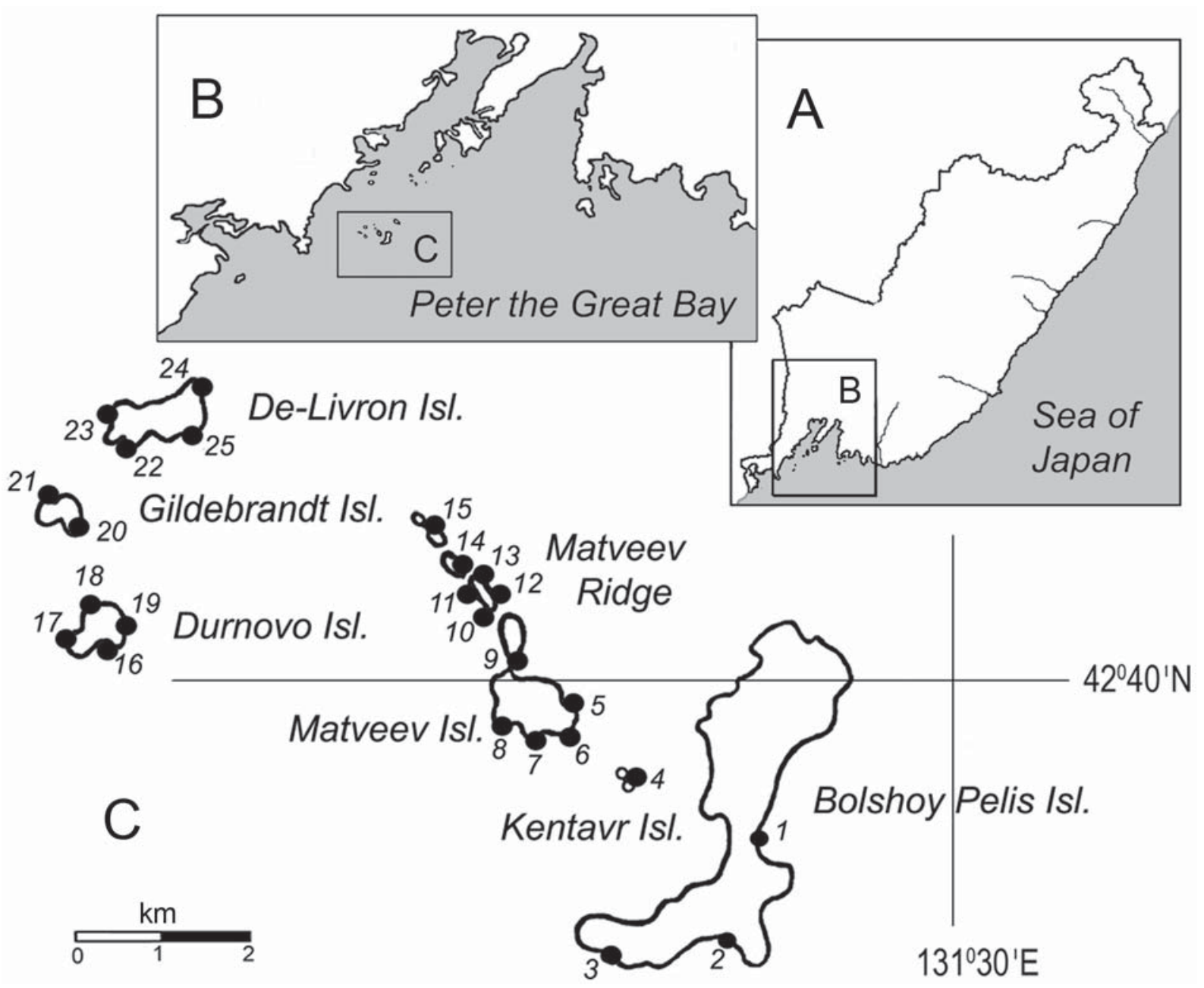

Figure 1. Location of spotted seal haulout sites on the islands of the Rimsky-Korsakov Archipelago (C) in Peter the Great Bay (B) of the Sea of Japan (A). Selected haulout site names are presented in Tab. 2.

\section{Materials and methods}

Study area. There are over 50 islands in Peter the Great Bay. However, more than $70 \%$ of all of the haulout sites of the spotted seal described in this region (Nesterenko \& Katin, 2009) are concentrated on the islands of the Rimsky-Korsakov Archipelago, which is situated in the southwestern part of the bay (Fig. 1) and consists of 10 islands that are grouped into two island clusters. The western cluster consists of Durnovo, Gildebrandt, and De-Livron Islands, which are located one $\mathrm{km}$ away from each other. Separated from the western cluster by the $6-8 \mathrm{~km}$ wide strait, the eastern cluster (Matveev Ridge) is composed of the closely located Matveev Island, the $1^{\text {st }}, 2^{\text {nd }}, 3^{\text {rd }}$, and $4^{\text {th }}$ Kamen Matveeva and Kentavr islands. The relatively large Bolshoy Pelis Island is regarded as independent archipelago component.

All of the haulout sites used for pupping are located on the islands of the Rimsky-Korsakov Archipelago, due to the features associated with their geomorphologic structure (Katin \& Nesterenko, 2010a). The reproductive ashore associations of the spotted seal (Nesterenko \& Katin, 2010) exist on 24 insular haulout sites (Fig. 1). The Rimsky-Korsakov Archipelago is located completely within the basin under the protection of the Far Eastern Marine Biosphere Reserve, so the presence of people there is strictly regulated.

Marking. Hot branding was used for marking of largha seal. This technique is the only method for obtaining lifelong marks that are unambiguously read at a distance (Merrick et al., 1996) and a number of modifications (Katin, 2010; Katin \& Nesterenko, 2010b) were developed to adapt this method to our study object (which has never been branded) and to the conditions of Peter the Great Bay. After determining sex and evaluating the general physical condition, an individual was weighed and branded to the left shoulder area with a number consisting of three Arabic numerals. For the genetic analysis, a sample of hair follicles was taken from each animal. 
Table 1. The number of resightings of spotted seals branded in 2009 on islands of the RimskyKorsakov Archipelago in 2009-2012.

\begin{tabular}{|l|c|c|c|c|}
\hline \multicolumn{1}{|c|}{ Resighting } & $\begin{array}{c}2009 \\
\text { (underyearlings) }\end{array}$ & $\begin{array}{c}2010 \\
\text { (yearlings) }\end{array}$ & $\begin{array}{c}2011 \\
\text { (two-year-old) }\end{array}$ & $\begin{array}{c}2012 \\
\text { (three-year-old) }\end{array}$ \\
\hline Total & 138 & 94 & 104 & 71 \\
\hline of which the branded seal was recorded: & \multicolumn{5}{|l|}{} \\
\hline 1 time & 86 & 59 & 64 & 46 \\
\hline 2 times & 34 & 24 & 28 & 15 \\
\hline 3 times & 12 & 8 & 8 & 2 \\
\hline 4 times & 6 & 2 & 2 & 1 \\
\hline 5 times & - & 1 & 2 & \\
\hline
\end{tabular}

The age group consisting of animals older than one month was selected for branding because of a number of reasons. First, after weaning, the animals have already begun an independent life, and the negative effect of the mother-pup relationship is eliminated. Second, young animals are connected with the coast of the archipelago during two-three months and are available for branding during this period. Third, there is a guarantee that the branded seals were born on the haulout sites within water area of the Rimsky-Korsakov Archipelago. Fourth, the young seals of this age group have a thick layer of fat and are sufficiently sized to endure the branding procedure without any negative consequences.

A total of 951 seals $(2009-170,2010-173$, 2011 - 200, 2012 - 178, 2013 - 230) have been branded over the five-year-long marking program. The data obtained from monitoring the individuals of one generation (specifically, the seals that were born on the Rimsky-Korsakov Archipelago islands in 2009) were used in this paper.

Resighting. The procedure of monitoring the branded seals required serious adaptations for the conditions of Peter the Great Bay. In our studies, the monitoring required not only recording of animals that haul out to a certain coastal place but systematic surveys of the archipelago basin by targeted searching for the branded animals on all islands. During the marking period (February-April), monitoring was carried out along with searching and capturing the seals that had not been branded. Later monitoring was carried out on a regular basis on days when the weather conditions allowed.

To search for the branded seals, we used aluminum boats produced in Russia ( 4.5 and $4.7 \mathrm{~m}$ long) that were equipped with Mercury-15 and Mercury-40 outboards. All the islands were examined along their perimeter at a minimal possible distance. At sites where it was difficult to examine the coast from aboard, landing was performed.

The first observation and branding of an animal was defined as the primary registration. All the subsequent times when this animal was observed were classified as resightings. For each resighting, we recorded the date and place where the animal was observed. We also characterized the condition of an animal, its behavior, and its contacts with other seals, in particular with those belonging to the same age group. All immature seals we have combined into four groups: pups (from birth to weaning), underyearlings (young-of-the-year animals in age up to 12 months), yearlings (one year old) and subadult seals older than one year (two- and three-yearold).

Ideally, the brand could be seen through the binoculars from a distance of up to $200 \mathrm{~m}$. However, in reality, when performing observations from a motorboat, the distance at which the digits could be reliably read was considerably smaller. When photographing with using a long-focal-length lens and short exposure times we usually obtained digital images, on which the even poorly readable mark could be reliably identified by computer processing. Therefore, we primarily used the photo registration method.

\section{Results and discussion}

A total 170 spotted seals have been marked on the Rimsky-Korsakov Archipelago islands in 2009. The sample of individuals branded in 2009 contained 90 males and 80 females. The sex ratio shift toward males was not statistically significant $\left(\chi^{2}=0.59, p>0.05\right)$.

Out of 170 seals, 69 and 83 individuals were branded on the islands of the western cluster and the eastern cluster, respectively. Eighteen animals were branded on the Bolshoy Pelis Island.

A total of 407 resightings were accumulated between 2009 and 2012 (Tab. 1). The evaluation of the use of space by underyearlings was based on 138 resightings with a reliably identified mark number for 86 individuals (for 34 of them from two to four resightings were recorded).

Based on data analysis from 269 accumulated between 2010 and 2012 resightings, we found that from 46 to 64 seals of 2009 generation were present in the breeding area, depending on the year. A total of 99 animals were registered at least once during the period between 2010 and 2012, and a total of 71 seals have not been registered since branding. However, amount of resightings does not tightly correlate with the mortality rate. For example, 21 individuals that were not resighted in 2010 were recorded in 2011 and eight animals that had never been registered since the times of branding were re-sighted in 2012. 


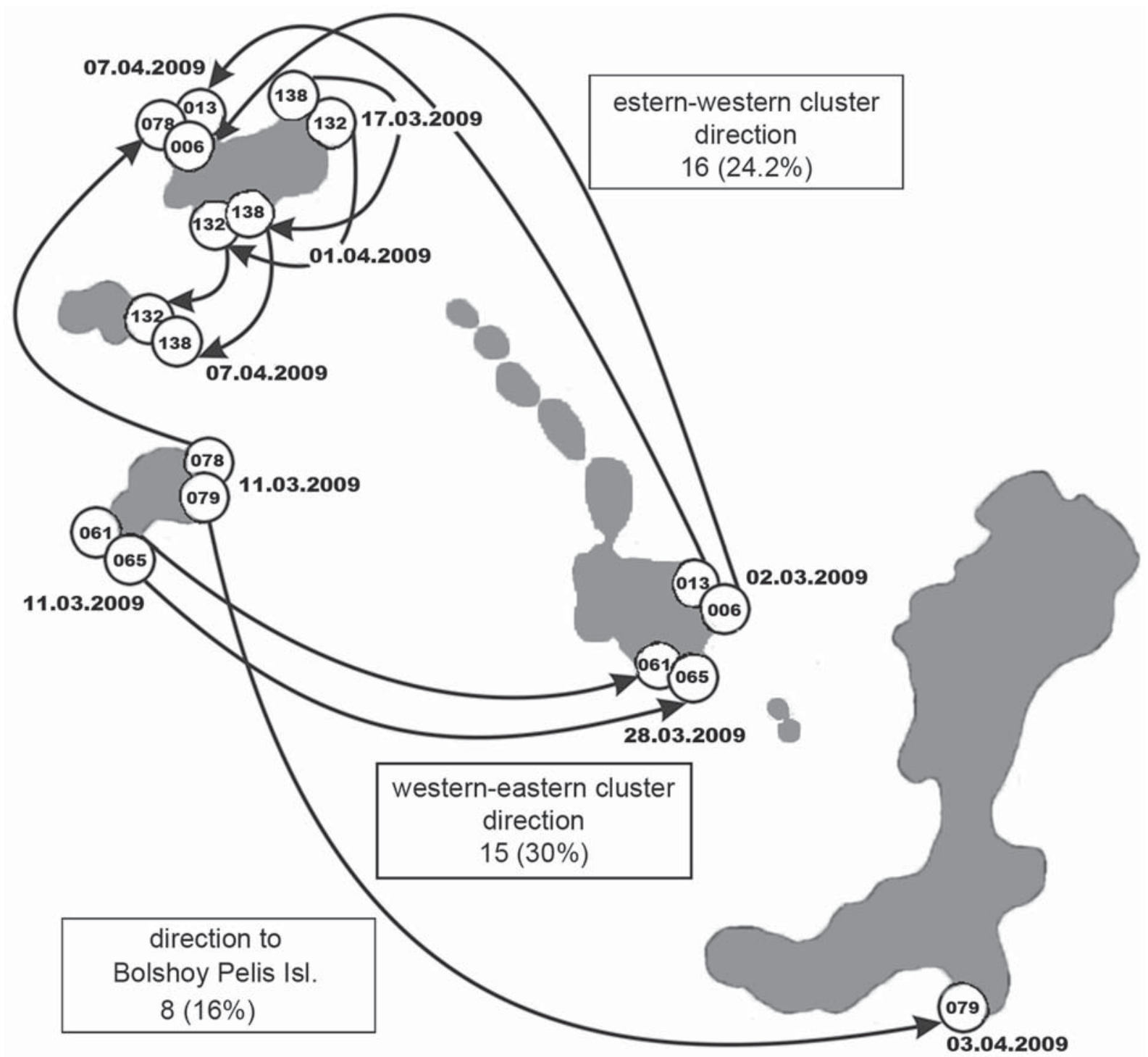

Figure 2. Selected movements of branded spotted seals (ID number of animals in the circle) and main directions of underyearling seal relocations (number of resightings and \% of its total number for each direction) within the RimskyKorsakov Archipelago.

Approximately 500 pups were born on the haulout sites of the archipelago in 2009. With allowance for the postnatal mortality rate, over $40 \%$ of the pups that survived to the stage of independent life were branded. No cases of death of branded animals were observed during the branding period and subsequent monitoring in 2009 .

The mortality rate of spotted seals during the first year of life may be as high as 45-50\% (Lowry, 1985; Trukhin, 2005) and it may be approximately $8-22 \%$ among immature animals older than one year according to various sources (Goltsev \& Fedoseev, 1970; Popov, 1976). Based on these data, 50 to 72 individuals could have survived until 2012 among the 170 seals branded in 2009. During the counts carried out in 2012, 46 seals that were branded in 2009 were registered (approxi- mately $70 \%$ of the branded seals that were theoretically expected to have survived to the age of three years).

Newborns start entering the water within the first days of life (Trukhin \& Katin, 2001, 2004). At an age of one-two weeks, pups can independently swim across small distances (mostly staying close to the shore). After weaning, the underyearlings leave the reproductive ashore associations. Some animals leave the breeding area, which is indicated by the observation of underyearlings in various regions of Peter the Great Bay. Other young seals remain in the Rimsky-Korsakov Archipelago basin and do not leave the coastal breeding region for several months, up to the beginning of the migration outflow from the bay (Katin \& Nesterenko, 2010b).

Use of space by underyearlings. After weaning, the underyearlings spend a lot of time on shore and some 
individuals may remain on the same spot of a beach without entering the water for several days. During this period, the underyearlings frequently use the coastal areas that are not used by seals of older age groups. We often observed the underyearlings on beaches far from the shoreline, among boulders, in the thickets of coastal vegetation, and even in the anthropogenic waste piles. Underyearlings use both haulout sites and coastal places not used by spotted seals of older age groups, including grottos and clefts that are hard-to-reach both from the shore and from the water. These sites appear to be preferred, as the safety requirements of the underyearlings drastically differ from those of the seals within ashore associations (Nesterenko \& Katin, 2009; Katin \& Nesterenko, 2010c).

Although the underyearlings spend abundant time ashore, they are not confined to the haulout sites where they were born or to any specific coastal areas. In fact, the underyearlings use the entire archipelago basin. Out of 138 resightings, $86.9 \%$ refer to animals that had repeated registration in the other parts of the archipelago than the site where they were branded. Forty two animals ( $24.7 \%$ of the total number of branded animals) were not observed at the site of primary registration.

Two types of relocations by spotted seal underyearlings were revealed. The first type of relocation is relocation of animals between the coastal zones of the islands belonging to the same cluster, and the second type is relocation between islands belonging to different archipelago clusters (Fig. 2).

No consistent directionality of relocation between islands within island clusters was detected. 50 resightings were registered for 69 underyearlings branded on the islands of the western cluster; $68 \%$ of those were observed only within this cluster. For example, male no. 078 was first registered on March 11, 2009 on Durnovo Island (Fig. 1: 19) and was subsequently relocated to De-Livron Island, where it was observed twice in different parts of the island. Female no. 089, branded on March 12, 2009 on De-Livron Island, was observed on Gildebrandt Island four weeks later and on Durnovo Island one week after that (Fig. 2).

A total of 66 resightings were registered for 83 animals branded on Matveev Ridge; $72.7 \%$ of the resightings were made on six islands of the eastern archipelago cluster. Some individuals relocated to adjacent sites on the same island. Male no. 113, branded on March 16, 2009 on Matveev Island (Fig. 1: 5), was observed on an adjacent haulout site 10 days later (Fig. 1: 9) and was later observed on the branding site again. Other underyearlings (e.g., nos. 103, 144, and 149) actively relocated between the islands of the eastern archipelago cluster.

The second type of young-of-the-year relocation is relocation between islands belonging to different clusters. The animals that had been branded on the islands of the Matveev Ridge were subsequently re-sighted on the islands of the western cluster $(24.2 \%) .30 \%$ of the resightings of the animals branded on the western clus- ter of islands occurred on the islands of the eastern cluster.

If the counter-current flows between the eastern and western island clusters were approximately equal, there was a trend of directional relocation by the underyearlings from different parts of the archipelago to Bolshoy Pelis Island. $16 \%$ and $16.6 \%$ of resightings registered for this island were of underyearlings that had relocated here from the islands of the western and eastern clusters, respectively. There are several potential reasons for relocation to the seaward side of Bolshoy Pelis Island. It is a large island and was relatively sparsely populated by seals during breeding period, compared to the rest of the islands within the archipelago. The island's coastline is long and indented. Thus, there are many places that are well protected from winds and drifting ice, thus ensuring a high degree of safety. It is also important to note that the adjacent underwater landscape contains a broad range of food objects that are available for young seals.

Despite the pronounced tendency towards relocation within the archipelago basin, some animals were confined to certain coastal areas during the entire period that the branded individuals were monitored. The number resightings that coincided with the site where the underyearling had originally been branded made up $13.1 \%$ of the total number of resightings. For example, within the period of slightly more than a month, female no. 076, branded on March 11, 2009 on Durnovo Island, was registered four times at this very site. Some underyearlings demonstrated fidelity to a certain coastal region, although the site where they had been branded did not coincide with the site of their subsequent registrations. For example, female no. 106, branded on March 13, 2009 on the $3^{\text {rd }}$ Kamen Matveeva, relocated to the neighboring $4^{\text {th }}$ Kamen Matveeva and was observed there three times until the end of March. Male no. 067, which was branded on March 11, 2009 on Durnovo Island (Fig. 1: 16), was repeatedly observed on March 26, 2009 on De-Livron Island (Fig. 1: 22) and was registered there twice up until April 14, 2009.

Thus, a significant fraction of the underyearlings that remain in the Rimsky-Korsakov Archipelago basin after weaning is tightly connected with the coastal areas of the islands. The underyearlings do not avoid the haulout sites where the reproductive ashore associations function. The younglings use these sites either as temporary resting places, or they demonstrate fidelity to a certain coastal region for an extended period of time.

During the monitoring period for the spotted seals branded in 2009, aggregations of underyearlings, consisting of both branded and unbranded individuals, were repeatedly observed. On March 31, 2009, spotted seals nos. 098, 102, 103, and 166 (branded on De-Livron, $3^{\text {rd }}$ and $4^{\text {th }}$ Kamen Matveeva, and Bolshoy Pelis Island, respectively) were simultaneously observed in the aggregation of underyearlings.

As a result of monitoring the branded individuals, we observed that certain animals demonstrated an in- 
Table 2. Abundance of immature individuals older than one year in molting ashore associations of the spotted seal on some haulout sites of the Rimsky-Korsakov Archipelago and the number of resightings of seals branded in 2009.

\begin{tabular}{|c|l|l|c|c|}
\hline No & \multicolumn{1}{|c|}{$\begin{array}{c}\text { Haulout site } \\
\text { (No. in Figure 1) }\end{array}$} & $\begin{array}{c}\text { Total number of resightings } \\
\text { of immature seals } \\
\text { in 2011-2012 }\end{array}$ & $\begin{array}{c}\text { Average number of } \\
\text { molting ashore } \\
\text { association }\end{array}$ \\
\hline 1 & Anti-Molchanskogo (1) & Bolshoy Pelis & 45 & 100 \\
\hline 2 & Kentavr (4) & Kentavr & 41 & 200 \\
\hline 3 & Tabletochnoye (10) & $2^{\text {nd }}$ Kamen Matveeva & 28 & 300 \\
\hline 4 & Olenye (21) & Gildebrandt & 27 & 100 \\
\hline 5 & Vostochnoye (5) & Matveev & 22 & $600-700$ \\
\hline 6 & Severo-zapadnoye (9) & Matveev & 16 & not formed \\
\hline 7 & Kabluk (2) & Bolshoy Pelis & 14 & 250 \\
\hline 8 & Minnoye (18) & Durnovo & 12 & \\
\hline
\end{tabular}

creased joint occurrence over a long period of time. Two females branded on March 2, 2009 on Matveev Island were simultaneously registered on De-Livron Island after five weeks. Two males that had been branded on March 17, 2009 on De-Livron Island were seen together on the same island two weeks later and observed on Gildebrandt Island another week later. A total of six resightings of paired observations indicate that some underyearlings maintain contacts over time by using the same coastal regions.

Use of space by immature seals older than one year within the archipelago. No differences in use of space by yearlings, two- and three-year-old spotted seals were detected. Thus, we combined these groups of seals when analyzing the use of space by immature spotted seals older than one year. Unlike underyearlings, immature seals older than one year use the island coasts only as a group. Only five of the 269 resightings consisted of single animals. It should be mentioned that all of these individuals were subsequently registered within a group.

Alliance of immature seals is open groups that are permanently replenished (Nesterenko \& Katin, 2012). As opposed to underyearlings, no significant relationships between the individuals in the same alliance were detected and the cases of joint registration within the same coastal aggregation of individuals captured for branding from the same haulout site (four cases out of 59 cases of joint registration) can be explained as a coincidence. Similar to the underyearlings, no differences in use of space by males and females were detected.

Immature spotted seals are dynamic in their use of space. According to the analysis of resightings, some seals exhibit a certain degree of fidelity to a specific coastal area. For example, male no. 022 was re-sighted four times on the Kentavr haulout site (Fig. 1: 4) in 2010 and four times — on the Anti-Molchanskogo haulout site (Fig. 1: 1) in 2011 (with a total number of 5 resightings this year). However, most spotted seals use the entire area of the archipelago for their relocations and sometimes change location rather quickly. For example, seal no. 079, which had been registered on the haulout site of one of the islands, was observed 30 minutes later on an island located two km away. Spotted seal no. 711 was registered four times in different haulout sites on both island clusters within a two hour time period (survey of the basin conducted on April 12, 2013).

Unlike the underyearlings, no patterns in the direction of relocations between the island clusters or between individual islands were observed as for yearlings and for immature spotted seals older than one year in general. However, unlike the underyearlings, immature spotted seals do not use places other than haulout sites for coming ashore. The haulout sites that are used are clearly subdivided into three groups. A total of five haulout sites are preferred (Tab. 2: 1-5). The number of resightings at these sites made up over $50 \%$ of the total number of all resightings registered during the survey period, fluctuating from 53.8 to $71.2 \%$ (61.3\% on average) for different years. The second group consisting of three haulout sites, where the number of resightings varied from 14.4 to $18.3 \%$ (15.8\% on average), was used less frequently (Tab. 2: 6-8). No more than five resightings were registered annually at the remaining haulout sites.

The first branded immature seals older than one year were registered on the haulout sites of the archipelago as early as in February. The first alliances originally consisted of several animals and were formed on Kentavr and Vostochnoye haulout sites. During the whelping period, which takes place from February to late March, the number of immature animals in the Rimsky-Korsakov Archipelago increases insignificantly, although groups consisting of three to 20 individuals occur everywhere. A substantial increase in the number of immature animals is observed in late March - early April. The size of their coastal aggregations increases to 50 and more animals during this period. Subsequently, the alliances of immature animals are replenished by adults that have finished mating. They unite and concentrate on several haulout sites. We referred to these associations as molting ashore associations (Nesterenko \& Katin, 2010).

There are significant functional differences between the alliances of immature animals and those of under- 
yearlings. The seals continuously relocate from one haulout site to another. The absence of agonistic relationships between the individuals makes it possible for an animal to join any group of spotted seals when hauling out. Such a rotational use of space is presumably the optimal mechanism for maintaining the maximum level of contacts between the animals in a colony. It is "social panmixia" that ensures the integrity of both the fraction of immature animals ( $\sim 40 \%$ of spotted seal population on the Rimsky-Korsakov Archipelago) and of the entire territorial grouping of the spotted seals in Peter the Great Bay.

On the haulout sites where the immature animals older than one year are present together with the underyearlings, these two fractions do not merge. The same is true for family groups as well. Immature spotted seals can be frightened easily and head to the water almost immediately after being disturbed, but the family groups and underyearlings remain in their locations. On the one hand, simultaneous presence on the haulout site ensures a high level of contact between all the animals belonging to different age groups, on the other hand, different fractions exist independently in their own dimension.

There is no conformity between the number of resightings accumulated during the spring season and the number of spotted seals in molting ashore associations. Although the group of haulout sites preferred by immature animals older than one year partially coincides with those used for the formation of molting ashore associations (Tab. 2), this is only because for forming of molting associations the haulout sites that allow the maximum concentration of animals are used. Such coast sites on the Rimsky-Korsakov Archipelago islands are adjoined spits or barrier spits that are formed by the accumulation of the abrasion products between two basement massifs. Only on eight haulout sites that possess this geomorphologic structure a total of 2,000 to 2,400 spotted seals annually gather in May.

After the molting ashore associations are formed, the spatial distribution of immature spotted seals changes. During this period, the immature animals become less active in respect to their relocations, and they are confined to the haulout sites hosting the molting ashore associations.

We found that $80 \%$ of approximately 2,500 spotted seals that concentrate in the Rimsky-Korsakov Archipelago basin during the reproductive and molting periods spend the remaining part of the year beyond Peter the Great Bay (Nesterenko \& Katin, 2012). The annual migration outflow starts after the disintegration of the molting ashore associations in May. During the summer period, there can be approximately 500 animals in Peter the Great Bay, but the permanent number of animals remaining within the Rimsky-Korsakov Archipelago is slightly higher than 100 . Most seals leave the breeding area in June and spread along the western coast of the Sea of Japan, migrate to the southern part of the Sea of Okhotsk and to the eastern coast of Hokkaido
Island (Trukhin \& Katin, 2004; Katin \& Nesterenko, 2012). Some immature animals migrated southwards up to Ulleung-Do Island (Katin \& Nesterenko, 2012), which is located near the eastern coast of Korea (approximately $750 \mathrm{~km}$ away from the branding site).

\section{Conclusion}

When considering the breeding area of the spotted seal in Peter the Great Bay in a broader sense, the entire basin of the bay is typically taken into account. However, one should keep in mind that during the breeding period reproductive colony of this species is confined to the Rimsky-Korsakov Archipelago. After becoming independent, some underyearlings leave the breeding zone and move over the basin of Peter the Great Bay, and others remain in the reproductive concentration zone and are tightly connected with the coastal areas for several months. After weaning, some offspring demonstrate fidelity to the certain sections of the coast, but most underyearlings use all of the islands of the archipelago. For their relocations within the archipelago and remaining ashore, they use all the available coastal places that provide adequate safety.

After becoming independent, the underyearlings withdraw from the reproductive ashore associations but do not avoid the haulout sites where associations of this type function. The underyearlings jointly use certain coastal regions to form dense aggregations, and some animals maintain individual contacts for a long time. Use of space by immature animals older than one year is fundamentally different. The spotted seals of this fraction relocate extensively over all the islands of the Rimsky-Korsakov Archipelago and use the coastal areas only in groups. These groups prefer haulout sites of a certain type. Immature spotted seals were not found to maintain individual contacts. However, due to the absence of antagonism, the maximum possible level of contacts with the other seals belonging to any fraction is ensured for each spotted seal. It is social panmixia that ensures the integrity of the entire territorial grouping of spotted seals.

In summer period most immature animals migrate from Peter the Great Bay but some seals do not leave the bay basin. The total number of residents does not exceed $20 \%$ of the number of all immature spotted seals.

\section{ACKNOWLEDGMENTS}

The authors are grateful to the Far Eastern Marine Biosphere State Reserve for support of this study. We would like to thank all those who helped to collect data. We give special thanks to the Marine Reserve staff members Andrei Gushchin and Stepan Anisimov for their work in the field. In adapting the hot-branding technique to the conditions of Peter the Great Bay, we are grateful for the knowledge of Mikhail Maminov and Aleksei Kuzin (TINRO-Centre). This work was supported by FEB RAS grants No. 12-I-DBS-10 and No. 12-III-A-06-076. 


\section{References}

Boveng P.L., Bengtson J.L., Buckley T.W., Cameron S.P., Dahle S.P., Kelly B.P., Megrey B.A., Overland J.E. \& Williamson N.J. 2009. Status Review of the Spotted Seal (Phoca largha). U.S. Department of Commerce. NOAA Technical Memorandum NMFS-AFSC-200. 146 p.

Goltsev V.N. \& Fedoseev G.A. 1970. [Dynamics of the age composition of rookeries and the replacement capacity of harbor seal populations] // Izvestiya TINRO. Vol.71. P.309-313 [in Russian, with English summary].

Katin I.O. 2010. Marking of spotted seal (Phoca largha) in the Peter the Great Bay // Marine Mammals of the Holarctic // Collection of Scientific Papers after the Sixth International Conference. Kaliningrad, Russia. P.252-255.

Katin I.O. \& Nesterenko V.A. 2010a. Oceanological conditions and reproduction of the spotted seal (Phoca largha) in Peter the Great Bay of the Sea of Japan // Oceanology. Vol.50. P.77-82.

Katin I.O. \& Nesterenko V.A. 2010b. [Territory used by spotted seal (Phoca largha) after transition to independent living in conditions of coastal reproduction] // Izvestiya TINRO. Vol.162. P.92-103 [in Russian, with English summary].

Katin I.O. \& Nesterenko V.A. 2010c. Inshore associations of the spotted seal (Phoca largha Pallas, 1811) // Contemporary Problems of Ecology. Vol.3. P.127-132.

Katin I.O. \& Nesterenko V.A. 2012. Homing of immature spotted seal (Phoca largha) by results of marking // Zoologicheskii Zhurnal. Vol.91. P.1273-1276 [in Russian, with English summary].

Lowry L.F. 1985. The spotted seal (Phoca largha) // Burns J.J., Frost K.J. \& Lowry L.F. (eds.). Marine Mammals Species Accounts. Juneau, AK: Alaska Department Fish and Game. P.89-96.
Merrick R.L., Loughlin T.R. \& Calkins D.C. 1996. Hot Branding: a Technique for Long-term Marking of Pinnipeds. U.S. Department of Commerce. NOAA Technical Memorandum NMFS-AFSC. 21 p.

Nesterenko V.A. \& Katin I.O. 2009. Haulout: scope of the term and procedure for identification // Russian Journal of Ecology. Vol.40. P.48-54.

Nesterenko V.A. \& Katin I.O. 2010. Cycle of transformation of the spotted seal (Phoca largha, Pallas, 1811) onshore associations in Peter the Great Bay of the Sea of Japan // Russian Journal of Marine Biology. Vol.36. P.47-55.

Nesterenko V.A. \& Katin I.O. 2012. [Quantitative characteristics of the spotted seal Phoca largha (Phocidae) grouping in Peter the Great Bay of the Sea of Japan] // Vestnik SNVT DVO RAN. No.2. P.19-8 [in Russian, with English summary].

Popov L.A. 1976. Status of main ice forms of seals inhabiting waters of the USSR and adjacent to the country marine areas // Scientific Consultation on Marine Mammals. Bergen: Food and Agriculture Organization of the United Nations. P.1-17.

Shaughnessy P.D. \& Fay F.H. 1977. A review of the taxonomy and nomenclature of North Pacific harbor seals // Journal of Zoology. Vol.182. P.385-419.

Trukhin A.M. 2005. [Largha]. Vladivostok: Dalnauka. 246 p. [In Russian, with English summary].

Trukhin A.M. \& Katin I.O. 2001. [On the question of breeding of the spotted seal in the Peter the Great Bay (Sea of Japan)] // Results of Marine Mammal Studies in the Far East in 1991-2000. Moscow: VNIRO. P.176-186 [in Russian].

Trukhin A.M. \& Katin I.O. 2004. [Current status of largha seal (Phoca largha Pallas)] // Far Eastern Marine Biosphere Reserve. Studies. Vladivostok: Dalnauka. P.481491 [in Russian]. 